\title{
E ffects of different processing technologies on chemical and antioxidant parameters of Macrolepiota procera wild mushroom
}

\author{
Ângela Fernandes ${ }^{\mathrm{a}, \mathrm{b}}$, Lillian B arros ${ }^{\mathrm{a}}$, J oão C.M . B arreira ${ }^{\mathrm{a}, \mathrm{b}}$, A milcar L. A ntonio ${ }^{\mathrm{a}, \mathrm{c}, \mathrm{d}}, \mathrm{M}$. \\ B eatriz P.P. Oliveirab, A nabela M artins ${ }^{a}$, Isabel C.F.R. Ferreira, ${ }^{a}{ }^{*}$
}

${ }^{a}$ Centro de Investigação de M ontanha (CIM O), ESA, Instituto Politécnico de Bragança Campus de Santa A polónia, A partado 1172, 5301-855 B ragança, Portugal.

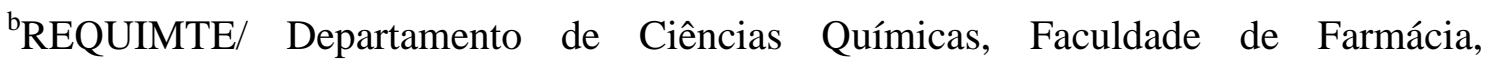
Universidade do Porto, Rua J orge V iterbo Ferreira n. 228, 4050-313 Porto, Portugal. 'IST/ITN, Instituto Tecnológico e Nuclear, Estrada Nacional 10, 2686-953 Sacavém, Portugal.

${ }^{d}$ Departamento de Física Fundamental, U niversidade de Sal amanca, Plaza de la M erced, 37008 Salamanca, Spain.

*Author to whom correspondence should be addressed (I.C.F.R. Ferreira: iferreira@ ipb.pt, tel. +351-273303219, fax +351-273325405). 


\section{A bstract}

Mushrooms are very perishable foods, demanding for processing technologies that retain chemical and nutritional characteristics of fresh forms. In this work, the influence of freezing, drying and gamma irradiation on chemical parameters and antioxidant potential of Macrolepiota procera was assessed through one-way ANOVA complemented with principal component analysis. Proximate composition was evaluated by AOAC procedures, while fatty acids, tocopherols and free sugars were determined using chromatographic techniques. A ntioxidant activity was measured using in vitro assays. $M$. procera samples have low energetic values, with moisture and carbohydrates as major nutrients. Linoleic, palmitic and oleic acids were the major fatty acids; !-tocopherol was the prevalent isoform in fresh, frozen and irradiated samples, while !-tocopherol predominated in dried samples. Trehalose was the most abundant sugar in fresh and irradiated samples, whereas mannitol predominated in frozen and dried samples. Dried samples gave higher DPPH scavenging activity and !-carotene bleaching inhibition; freeze and irradiated samples showed higher reducing power and TBARS formation inhibition, respectively. Overall, freezing and drying caused significant differences in chemical parameters. On the other hand, gamma irradiation revealed the highest capacity to retain chemical profile of fresh samples, which highlights its potential to be explored and validated as an alternative conservation methodology.

Keywords: Processing technology; M acrolepiota procera; Chemical composition; A ntioxidant activity; Freezing/D rying/Gamma-irradiation 


\section{Introduction}

M ushrooms are widely appreciated for their unique taste and flavor, but also for their nutritional (Kala", 2009) and medicinal properties, such as anti-inflammatory, antidiabetic, antibacterial and antitumor, attributed to the presence of bioactive metabolites (e.g. phenolic compounds, terpenes, steroids and polysaccharides) (Poucheret, Fons, \& Rapior, 2006; Ferreira, Vaz, Vasconcelos, \& M artins, 2010). In particular, edible mushrooms can be a source of nutraceuticals with important antioxidant properties, which can positively influence the oxidative stress in cells and related diseases (Ferreira, Barros, \& A breu, 2009).

$\mathrm{N}$ evertheless, mushrooms are one of the most perishable food products and tend to lose quality immediately after harvest. The shelf life is reduced due to post-harvest changes, namely browning, cap opening, stipe elongation, cap diameter increase, weight loss and texture damage, related to their high respiration rate and moisture, relatively high protein content, and lack of physical protection to avoid water loss or microbial attack (Fernandes, A ntonio, Oliveira, M artins, \& Ferreira, 2012c). Therefore, mushrooms are mainly used in the processed form (J aworska \& B ernás, 2009).

Extending shelf-life is an imperative factor to increase the profitability and availability of any food product, since it offers the possibility of developing markets at a greater distance (A kram \& K won, 2010), but the applied technology should not act itself as a source of chemical modifications.

Drying is the most common method for preserving mushrooms (Giri \& Prasad, 2007) and freezing is becoming increasingly popular (J aworska \& Bernás, 2009; J aworska \& Bernás, 2010). Drying is a comparatively cheaper method (Rama \& Jacob, 2000; Walde, Velu, Jyothirmayi, \& Math, 2006), while food freezing is among the most efficient and adequate preservation methods (Haiying, Shaozhi, \& Guangming, 2007). 
The main advantage of freezing is that it allows the best retention of nutritional value as well as sensory qualities such as color, aroma, taste and texture; during freezing most of the liquid water changes into ice, which greatly reduces microbial and enzymatic activities (Haiying et al. 2007).

Food irradiation has also been suggested as a safe and adequate process to maintain and increase the food shelf life (WHO, 1994). This physical method of conservation involves exposing a product to ionizing radiation, in a controlled dose and irradiation time (A kram \& K won, 2010; Fernandes et al. 2012c). The maximal recommended dose for extending the shelf-life of fresh mushrooms is 3 kG y (ICGFI, 1999).

M any studies have applied gamma irradiation to a range of mushrooms including cultivated (J iang, Luo, Chen, Shen, \& Y ing, 2010; Sommer, Schwart, Solar, \& Sontag, 2010) and, more recently, wild species (Fernandes et al., 2012a; Fernandes et al., 2012b). In those two studies of our research group, the effects of gamma irradiation on chemical composition, antioxidant activity and physical parameters of fresh Lactarius deliciosus wild edible mushroom were evaluated, being concluded that up to $1 \mathrm{kG}$ this technology was effective in maintaining chemical composition and controlling the deterioration of fresh samples.

The main objective of the present study was to assess the effects of different processing technologies (freezing, drying and gamma irradiation) on chemical and antioxidant parameters of the wild mushroom Macrolepiota procera, in order to select the most suitable solution to be applied in future studies related to its preserving ability.

\section{M aterials and methods}

\subsection{Standards and reagents}


To estimate the dose and dose rate a Fricke dosimeter was used. This consists of a chemical solution sensitive to ionizing radiation, prepared in the laboratory following the standards and A mber Perspex dosimeters (batch V, from Harwell Dosimeters, Harwell, UK). To prepare the acid aqueous Fricke dosimeter solution the following reagents were used: ferrous ammonium sulfate(II)hexahydrate, sodium chloride and sulfuric acid, all of them purchased from Panreac S.A. (Barcelona, Spain) with purity PA (proanalysis).

For chemical analyses: acetonitrile $99.9 \%, \mathrm{n}$-hexane $95 \%$ and ethyl acetate $99.8 \%$ were of HPLC grade from Lab-Scan (Lisbon, Portugal). The fatty acids methyl ester (FAME) reference standard mixture 37 (standard $47885-\mathrm{U}$ ) was purchased from Sigma (St. Louis, M O, USA), as also other individual fatty acid isomers, tocopherol and sugar standards. Racemic tocol, $50 \mathrm{mg} / \mathrm{mL}$, was purchased from M atreya (Pleasant Gap, PA, USA).

For antioxidant potential analysis: 2,2-diphenyl-1-picrylhydrazyl (DPPH) was obtained from Alfa Aesar (Ward Hill, MA, USA). Standards trolox (6-hydroxy-2,5,7,8tetramethylchroman-2-carboxylic acid) and gallic acid were from Sigma (St. Louis, M O, USA). M ethanol and all other chemicals were of analytical grade and obtained from common sources. W ater was treated in a Milli-Q water purification system (TGI Pure W ater Systems, Greenville, SC, USA ).

\subsection{Samples and samples preparation}

M acrolepiota procera fruiting bodies were obtained in Trás-0s-M ontes, in the N ortheast of Portugal, in November 2011. The samples were divided into four groups with three mushrooms (whole fruiting bodies) per group with different stages of maturation, and then submitted to different processing technologies: freezing (at $-20{ }^{\circ} \mathrm{C}$ in a freezer), 
drying (at $30{ }^{\circ} \mathrm{C}$ in an oven) and gamma irradiation (with a Co-60 source, following the procedure previously described by us; Fernandes et al., 2012a). The estimated dose after irradiation was $0.6 \pm 0.1 \mathrm{kGy}$, at a dose rate of $2.3 \pm 0.1 \mathrm{kGy} \mathrm{h}^{-1}$. The fourth group was kept fresh and promptly analyzed (control sample).

A fter each treatment, the samples were lyophilized (FreeZone 4.5 model 7750031, Labconco, Kansas, USA) to prevent any further deterioration, reduced to a fine dried powder $(0.85 \mathrm{~mm})$ and mixed to obtain homogenized samples for subsequent analyses.

\subsection{Chemical composition}

2.3.1. Proximate composition. Moisture, protein, fat, carbohydrates and ash were determined following the AOAC procedures (AOAC, 1995). The crude protein content ( $\mathrm{N}$ \# 4.38) of the samples was estimated by the macroK jeldahl method; the crude fat was determined by extracting a known weight of the sample with petroleum ether, using a Soxhlet apparatus; the ash content was determined by incineration at $600 \pm 15^{\circ} \mathrm{C}$; total carbohydrates were calculated by difference: total carbohydrates $(\mathrm{g})=100$ - (g moisture $+\mathrm{g}$ protein $+\mathrm{g}$ fat $+\mathrm{g}$ ash). Total energetic value $(100 \mathrm{~g})$ was calculated according to the following equation: energetic value $(\mathrm{kcal})=4 \#(\mathrm{~g}$ protein $+\mathrm{g}$ carbohydrate $)+9 \#(\mathrm{~g}$ fat).

2.3.2. Fatty acids. Fatty acids were determined after a transesterification procedure as described previously by the authors (Heleno, B arros, Sousa, M artins, \& Ferreira, 2009), using a gas chromatograph (DANI 1000, Contone, Switzerland) equipped with a split/splitless injector and a flame ionization detector (GC-FID). Fatty acids identification was made by comparing the relative retention times of FAM E peaks from samples with standards. The results were recorded and processed using CSW 1.7 
software (DataA pex 1.7). The results were expressed in $\mathrm{g}$ per $100 \mathrm{~g}$ of fat (obtained after Soxhlet extraction).

2.3.3. Free sugars. Free sugars were determined by a High Performance Liquid Chromatography (HPLC) system consisted of an integrated system with a pump (K nauer, Smartline system 1000, Berlin, Germany), degasser system (Smartline manager 5000) and auto-sampler (A S-2057 Jasco, MD, USA), coupled to a refraction index detector (RI; detector Knauer Smartline 2300, Berlin, Germany) as previously described by the authors (Heleno et al., 2009). Identification of sugars was made by comparing the relative retention times of sample peaks with standards. Data were analyzed using Clarity 2.4 Software (DataA pex). Quantification was based on the RI signal response of each standard, using the internal standard (IS, raffinose) method and by using calibration curves obtained from commercial standards of each compound. The limits of detection ( $L O D$ ), calculated as the concentration corresponding to three times the calibration error divided by the slope, were $0.05 \mathrm{mg} / \mathrm{mL}$ for fructose, and 0.07 $\mathrm{mg} / \mathrm{mL}$ for mannitol, trehalose and melezitose. The limits of quantification ( $L O Q$ ) were calculated using the concentration corresponding to ten times the calibration error divided by the slope, and were $0.18 \mathrm{mg} / \mathrm{mL}$ for fructose and melezitose, and 0.22 and $0.24 \mathrm{mg} / \mathrm{mL}$ for mannitol and trehalose respectively). The results were expressed in $\mathrm{g}$ per $100 \mathrm{~g}$ dry weight (dw).

2.3.4. Tocopherols. Tocopherols were determined following a procedure previously optimized and described by the authors (Barros, Correia, Ferreira, Baptista, $\&$ SantosBuelga, 2008). A nalysis was performed by HPLC (equipment described above), and a fluorescence detector (FP-2020; J asco, Easton, M D, USA ) programmed for excitation at 
$290 \mathrm{~nm}$ and emission at $330 \mathrm{~nm}$. The compounds were identified by chromatographic comparison with authentic standards. Quantification was based on the fluorescence signal response of each standard, using the IS (tocol) method and by using calibration curves obtained from commercial standards of each compound. LOD values were 8.49, 20.03, 20.08, $20.09 \mathrm{ng} / \mathrm{mL}$ for \$-, !-, \% and \&tocopherol, respectively; LOQ values were $28.29,66.77,66.93$ and $66.95 \mathrm{ng} / \mathrm{mL}$ for $\$-,,-, \%$ and \&tocopherol, respectively. The results were expressed in ' $\mathrm{g}$ per $100 \mathrm{~g} \mathrm{dw}$.

\subsection{Antioxidant activity}

2.4.1. Extraction procedure. The lyophilized powder $(1 \mathrm{~g})$ was stirred with methanol (30 mL) at $25{ }^{\circ} \mathrm{C}$ at $150 \mathrm{rpm}$ for $1 \mathrm{~h}$ and filtered through Whatman No. 4 paper. The residue was then extracted with an additional portion of methanol. The combined methanolic extracts were evaporated under reduced pressure (rotary evaporator B üchi R-210; Flawil, Switzerland), re-dissolved in methanol at $20 \mathrm{mg} / \mathrm{mL}$ (stock solution), and stored at $4 \stackrel{\circ}{\mathrm{O}} \mathrm{C}$ for further use. Successive dilutions were made from the stock solution and submitted to in vitro assays already described by the authors (Barros, Baptista, Correia, M orais, \& Ferreira, 2007) to evaluate the antioxidant activity of the samples. The sample concentrations providing $50 \%$ of antioxidant activity or 0.5 of absorbance $\left(\mathrm{EC}_{50}\right)$ were calculated from the graphs of antioxidant activity percentages (DPPH, !-carotene/linoleate and TBARS assays) or absorbance at $690 \mathrm{~nm}$ (reducing power assay) against sample concentrations. Trolox was used as standard.

2.4.2. Total phenolics. Phenolics were determined by the Folin-Ciocalteu assay. The extract solution $(1 \mathrm{~mL})$ was mixed with Folin-Ciocalteu reagent $(5 \mathrm{~mL}$, previously diluted with water $1: 10, v / v)$ and sodium carbonate $(75 \mathrm{~g} / \mathrm{L}, 4 \mathrm{~mL})$. The tubes were 
vortex mixed for $15 \mathrm{~s}$ and allowed to stand for $30 \mathrm{~min}$ at $40{ }^{\circ} \mathrm{C}$ for colour development. A bsorbance was then measured at $765 \mathrm{~nm}$. Gallic acid was used to obtain the standard curve $(0.0094-0.15 \mathrm{mg} / \mathrm{mL})$, and the results were expressed as $\mathrm{mg}$ of gallic acid equivalents (GAE) per $g$ of extract.

2.4.3. DPPH radical scavenging activity. This methodology was performed using an ELX 800 Microplate Reader (Bio-Tek, Winooski, VT, USA). The reaction mixture in each one of the 96-wells consisted of one of the different concentrations of the extracts (30 ' L) and methanolic solution (270 ' L) containing DPPH radicals (6 \#10-5 $\mathrm{mol} / \mathrm{L}$ ). The mixture was left to stand for $60 \mathrm{~min}$ in the dark. The reduction of the DPPH radical was determined by measuring the absorption at $515 \mathrm{~nm}$. The radical scavenging activity (RSA) was calculated as a percentage of DPPH discolouration using the equation: \% $R S A=\left[\left(A_{D P P H}-A_{S}\right) / A_{D P P H}\right] \# 100$, where $A_{s}$ is the absorbance of the solution when the sample extract has been added at a particular level, and A DPPH is the absorbance of the DPPH solution.

2.4.4. Reducing power. This methodology was performed using the Microplate Reader described above. The different concentrations of the extracts $(0.5 \mathrm{~mL})$ were mixed with sodium phosphate buffer (200 mmol/L, $\mathrm{pH} 6.6,0.5 \mathrm{~mL}$ ) and potassium ferricyanide (1 $\mathrm{g} / 100 \mathrm{~mL}, 0.5 \mathrm{~mL}$ ). For each concentration, the mixture was incubated at $50{ }^{\circ} \mathrm{C}$ for 20 $\mathrm{min}$, and trichloroacetic acid $(10 \mathrm{~g} / 100 \mathrm{~mL}, 0.5 \mathrm{~mL})$ was added. The mixture $(0.8 \mathrm{~mL})$ was poured in the 48-wells, as also deionised water $(0.8 \mathrm{~mL})$ and ferric chloride $(0.1$ $\mathrm{g} / 100 \mathrm{~mL}, 0.16 \mathrm{~mL}$ ), and the absorbance was measured at $690 \mathrm{~nm}$. 
2.4.5. Inhibition of !-carotene bleaching. !-carotene $(2 \mathrm{mg})$ was dissolved in chloroform (10 mL) and $2 \mathrm{~mL}$ of this solution were pipetted into a round-bottom flask. A fter the chloroform was removed at $40 \stackrel{\circ}{\mathrm{C}}$ under vacuum, linoleic acid (40 mg), Tween 80 emulsifier $(400 \mathrm{mg})$, and distilled water $(100 \mathrm{~mL})$ were added to the flask with vigorous shaking. A liquots $(4.8 \mathrm{~mL})$ of this emulsion were transferred into different test tubes containing different concentrations of the extracts $(0.2 \mathrm{~mL})$. The tubes were shaken and incubated at $50 \stackrel{\circ}{\mathrm{C}}$ in a water bath. As soon as the emulsion was added to each tube, the zero time absorbance was measured at $470 \mathrm{~nm}$. !-Carotene bleaching inhibition was calculated using the following equation: (Absorbance after $2 \mathrm{~h}$ of assay/initial A bsorbance) \#100.

2.4.6. TBARS assay. Porcine (Sus scrofa) brains were obtained from animals slaughtered at officially licensed premises, dissected, and homogenized with a Polytron in ice cold Tris- $\mathrm{HCl}$ buffer $(20 \mathrm{mmol} / \mathrm{L}, \mathrm{pH} 7.4)$ to produce a brain tissue homogenate $(0.5 \mathrm{~g} / \mathrm{mL})$ which was centrifuged at $3000 \mathrm{~g}$ for $10 \mathrm{~min}$. An aliquot $\left(100^{\prime} \mathrm{L}\right)$ of the supernatant was incubated with the different concentrations of the samples solutions $\left(200{ }^{\prime} \mathrm{L}\right)$ in the presence of $\mathrm{FeSO} 4(10 \mathrm{mmol} / \mathrm{L} ; 100 ' \mathrm{~L})$ and ascorbic acid $(0.1$ $\left.\mathrm{mmol} / \mathrm{L} ; 100^{\prime} \mathrm{L}\right)$ at $37 \stackrel{\text { o }}{\mathrm{C}}$ for $1 \mathrm{~h}$. The reaction was stopped by the addition of trichloroacetic acid (28 g/100 mL, 500 ' L), followed by thiobarbituric acid (TBA, 2 $\left.\mathrm{g} / 100 \mathrm{~mL}, 380^{\prime} \mathrm{L}\right)$, and the mixture was then heated at $80{ }^{\circ} \mathrm{C}$ for $20 \mathrm{~min}$. After centrifugation at $3000 \mathrm{~g}$ for 10 min to remove the precipitated protein, the colour intensity of the malondialdehyde (MDA)-TBA complex in the supernatant was measured at $532 \mathrm{~nm}$. The inhibition ratio (\%) was calculated using the following formula: Inhibition ratio $(\%)=[(A-B) / A] \# 100 \%$, where $A$ and $B$ were the absorbance of the control and the sample solution, respectively. 


\subsection{Statistical analysis}

For each processing technology three samples were analysed, with all the assays being also carried out in triplicate. Data were expressed as meantstandard deviation. All statistical tests were performed at a 5\% significance level using SPSS software, version 18.0.

2.5.1. Analysis of variance. The fulfillment of the one-way ANOVA requirements, specifically the normal distribution of the residuals and the homogeneity of variance, was tested by means of the Shapiro-Wilk's and the Levene's tests, respectively. All dependent variables were compared using Tukey's honestly significant difference (HSD) or Tamhane's T2 multiple comparison tests, when homoscedasticity was verified or not, respectively.

2.5.2. Principal components analysis (PCA). PCA was applied as the pattern recognition unsupervised classification method. PCA transforms the original, measured variables into new uncorrelated variables called principal components. The first principal component covers as much of the variation in the data as possible. The second principal component is orthogonal to the first and covers as much of the remaining variation as possible, and so on (Patras et al., 2011). The number of dimensions considered for PCA was chosen in order to allow meaningful interpretations, and by ensuring their reliability.

\section{R esults and discussion}




\subsection{Chemical composition}

Table 1 shows the mean values obtained for proximate composition of M. procera mushrooms submitted to different processing technologies. In general, the values are similar to those reported in previous studies (Barros et al., 2007; O uzouni \& Riganakos, 2007), except for higher protein and lower carbohydrates content than those observed by Barros et al. (2007). M oisture was the major component, followed by carbohydrates (60 to $70 \mathrm{~g} / 100 \mathrm{~g} \mathrm{dw}$ ) and proteins (19 to $29 \mathrm{~g} / 100 \mathrm{~g} \mathrm{dw}$ ). The mean values of all the assayed parameters revealed significant differences $(p<0.05)$ among the processing technologies, mainly for carbohydrates, ash and energetic value. Freezing prevented proteins degradation observed in the other samples, which could be related to cell wall disruption induced by low temperatures. Irradiation prevented the fat decrease verified in the other samples, probably due to a decrease in molecular oxygen, which is known to induce lipid auto-oxidation processes ( $\mathrm{N}$ awar, 1986).

Table 2 presents the mean values obtained for fatty acid profiles. Besides the tabled compounds, C6:0, C8:0, C10:0, C12:0, C14:1, C17:0, C18:3, C20:0, C20:1, C20:3, C21:0, C20:5, C22:0, C22:1, C23:0 and C24:1 were also detected, but in trace amounts $(<0.3 \mathrm{~g} / 100 \mathrm{~g}$ of fat). The statistical analysis showed homoscedastic distribution, except for C14:0 and C15:0. One-way A N OV A demonstrated significant statistical differences among the contents in fatty acids, especially for C15:0, C18:0, C18:1 and total monounsaturated fatty acids (MUFA). Dried and irradiated samples exhibited higher percentages of saturated fatty acids (SFA), while MUFA were higher in irradiated samples, and polyunsaturated fatty acids (PUFA) reached maximal values in frozen samples. Despite some differences regarding individual fatty acids, the global percentages obtained for SFA, MUFA and PUFA are similar to those presented in other studies (K avishree, Hemavathy, L okesh, Shashirekha, \& Rajarathnam, 2008). 
The mean values obtained for tocopherol profiles are given in Table 3. Once again, the results of the Levene's test confirmed the homoscedasticity of distribution in all cases. At a $5 \%$ significance level, $\forall$ and !-tocopherols were the vitamers with the highest variability, but other statistical differences could be observed, proving that tocopherol profiles obtained for each technology were dissimilar. For instance, irradiated samples showed the highest contents of $\$-\left(5.2^{\prime} \mathrm{g} / 100 \mathrm{~g} \mathrm{dw}\right)$ and $\forall$ tocopherol (43 ' $\left.\mathrm{g} / 100 \mathrm{~g} \mathrm{dw}\right)$, while dried and fresh samples had the highest contents in !- (77 ' g/100 g dw) and !tocopherol (91 ' $\mathrm{g} / 100 \mathrm{~g}$ of $\mathrm{dw}$ ), respectively.

Regarding free sugars composition (Table 4), dried samples gave the highest total content (19.3 g/100 g dw), also presenting the highest levels of mannitol $(11.4 \mathrm{~g} / 100 \mathrm{~g}$ $\mathrm{dw})$. The highest concentration of trehalose $(10.2 \mathrm{~g} / 100 \mathrm{~g} \mathrm{dw})$ and melezitose (1.42 $\mathrm{g} / 100 \mathrm{~g} \mathrm{dw})$ was found in irradiated samples, while fructose $(0.17 \mathrm{~g} / 100 \mathrm{~g} \mathrm{dw})$ was higher in frozen samples. Fresh and irradiated samples presented trehalose as the main sugar, whereas mannitol predominated in frozen and dried samples. Trehalose, melezitose and total free sugars gave the most significant differences among processing technologies. The amounts quantified for the main sugars (trehalose and mannitol) are in agreement with previous results concerning different treatments applied to $M$. procera samples (B arros et al., 2007).

\subsection{Antioxidant activity}

All M. procera samples proved to have antioxidant activity, but revealed different properties according to the applied processing technology. Dried samples had the highest antioxidant activity (Table 5), measured by DPPH scavenging activity (50\% at $2.7 \mathrm{mg} / \mathrm{mL}$ ) and !-carotene bleaching inhibition (50\% at $1.10 \mathrm{mg} / \mathrm{mL})$. Accordingly, these were also the samples with the highest phenolic content (19.2 mg GAE/g extract). 
However, the methanolic extracts obtained from frozen and irradiated samples presented the highest reducing power (0.5 absorbance at $1.27 \mathrm{mg} / \mathrm{mL}$ ) and TBARS formation inhibition ( $50 \%$ at $0.78 \mathrm{mg} / \mathrm{mL}$ ), respectively. Regarding frozen samples, the cell walls might be disrupted increasing the extractability of intracellular compounds, leading to the highest reducing power. The heat $\left(30^{\circ} \mathrm{C}\right.$ ) applied to dried samples could inactivate endogenous oxidative enzymes ( $B$ arros et al., 2007), explaining the increased antioxidant activity.

In general, and independently of the processing technology, M. procera samples have low energetic values (372-388 $\mathrm{kcal} / 100 \mathrm{~g} \mathrm{dw})$, with moisture and carbohydrates as major nutrients. The fatty acid profiles were similar for all the samples: linoleic, palmitic and oleic acids were the compounds present in major amounts. !-Tocopherol was the prevalent vitamin E isoform in fresh, frozen and irradiated samples, while !tocopherol predominated in dried samples. Regarding free sugars, trehalose was the most abundant compound in fresh and irradiated samples, whereas mannitol was the main sugar in frozen and dried samples. The processing technologies had specific effects on the antioxidant potential of M. procera extracts: dried samples gave higher DPPH scavenging activity and !-carotene bleaching inhibition; freeze samples showed higher reducing power and irradiated samples revealed higher TBARS formation inhibition.

\subsection{Principal Components Analysis (PCA)}

For a better comprehension of the differences induced by each processing technology, data were evaluated through a PCA. The number of dimensions considered in the analysis was set in order to obtain meaningful outputs. The reliability of dimensions was ensured by Cronbach's al pha parameter (that must be positive) and eigenvalue (that 
should be higher than 1). The plot of object points (Figure 1A) indicates that the first two dimensions account for most of the variance of all quantified variables $(57.19 \%$ and $27.46 \%$, respectively). The parameters most correlated with the first dimension are highlighted (black dashed line) in Figure 1B. As it can be observed in Figure 1, these variables have a high impact especially within frozen samples, that are clearly separated mostly due to their high content of fructose, proteins, C18:2, PUFA, or the high $\mathrm{EC}_{50}$ values obtained for !-carotene bleaching inhibition. On the other hand, the variables most correlated with the second dimension are highlighted with dotted grey lines. These have a significant influence on dried samples, that were separated especially due to their high contents in mannitol, ash or ! -tocopherol (Figure 1B).

Overall, irradiation was the processing technology with the highest ability to maintain the chemical profile of the fresh samples, indicating its high potential to be explored and validated as a conservation methodology for wild mushrooms. In fact, the spatial distribution of PCA markers (Figure 1A) indicates clearly that the processes of freezing and drying induced much higher differences in the evaluated chemical parameters.

\section{Acknowledgements}

The authors are grateful to the Foundation for Science and Technology (FCT, Portugal) for financial support of research centres CIMO (PEst-OE/AGR/UI0690/2011) and REQUIMTE (PEst-C/EQB/LA 0006/2011). Â. Fernandes, L. Barros, J.C.M. Barreira and A.L. Antonio thank FCT, POPH-QREN and FSE for their grants (SFRH/BD/76019/2011， SFRH/BPD/4609/2008， SFRH/BPD/72802/2010 and SFRH/PROTEC/67398/2010, respectively).

\section{R eferences}


A kram, K., \& K won, J.-H. (2010). Food Irradiation for M ushrooms: A Review. J ournal of Korean Society for Applied Biological Chemistry, 53, 257-265.

AOAC. (1995). Official methods of analysis (16 ${ }^{\text {th }}$ Ed.). A rlington VA, USA: A ssociation of Official A nalytical Chemists.

Barros, L., Baptista, P., Correia, D.M., Sá M orais, J., \& Ferreira, I.C.F.R. (2007). Effects of conservation treatment and cooking on the chemical composition and antioxidant activity of Portuguese wild edible mushrooms. J ournal of Agricultural and F ood Chemistry, 55, 4781-4788.

Barros, L., Correia, D.M ., Ferreira, I.C.F.R., Baptista, P., \& Santos-Buelga, C. (2008). Optimization of the determination of tocopherols in Agaricus sp. edible mushrooms by a Normal Phase Liquid Chromatographic method. Food Chemistry, 110, 1046-1050.

Fernandes, Â., Antonio, A.L., Barreira, J.C.M., Botelho, L., Oliveira, M.B.P.P., Martins, A., \& Ferreira, I.C.F.R. (2012a). Effects of gamma irradiation on the chemical composition and antioxidant activity of Lactarius deliciosus L. wild edible mushroom. Food and Bioprocess Technology, doi 10.1007/s11947-0120931-5.

Fernandes, A., A ntonio, A.L., Barreira, J.C.M., Oliveira, M.B.P.P., M artins, A., \& Ferreira, I.C.F.R. (2012b). Effects of gamma irradiation on physical parameters of Lactarius deliciosus wild edible mushroom. Postharvest Biology and Technology, $74,79-84$.

Fernandes, Â., Antonio, A.L., Oliveira, M.P.P., Martins, A., \& Ferreira, I.C.F.R. (2012c). Effect of gamma and electron beam irradiation on the physico-chemical and nutritional properties of mushrooms: A review. Food Chemistry, 135, 641650. 
Ferreira, I.C.F.R., Barros, L., \& Abreu, R.M.V. (2009). Antioxidants in wild mushrooms. Current M edicinal Chemistry, 16, 1543-1560.

Ferreira, I.C.F.R., Vaz, J.A., Vasconcelos, M.H., \& Martins, A. (2010). Compounds from wild mushrooms with antitumor potential. Anti-cancer Agents in Medicinal Chemistry, 10, 424-436.

Giri, S. K., \& Prasad, S. (2007). Drying kinetics and rehydration characteristics of microwave-vacuum and convective microwave-vacuum and convective hot-air dried mushrooms. J ournal of F ood Engineering, 78, 512-552.

Haiying, W., Shaozhi, Z., \& Guangming, C. (2007). Experimental study on the freezing characteristics of four kinds of vegetables. LWT - Food Science and Technology, $40,1112-1116$

Heleno, S.A., Barros, L., Sousa, M.J., Martins, A., \& Ferreira, I.C.F.R. (2009). Study and characterization of selected nutrients in wild mushrooms from Portugal by gas chromatography and high performance liquid chromatography. Microchemical J ournal, 93, 195-199.

ICGFI. International Consultative G roup on Food Irradiation. (1999). In Facts about Food Irradiation. Buckinghamshire, U nited K ingdom.

Jaworska, G., \& Bernás, E. (2009). The effect of preliminary processing and period of storage on the quality of frozen Boletus edulis (Bull: Fr.) mushrooms. Food Chemistry, 113, 936-943.

Jaworska, G., \& Bernás, E. (2010). Effects of pre-treatment, freezing and frozen storage on the texture of Boletus edulis (Bull: Fr.) mushrooms. International J ournal of refrigeration, 33, 877-885.

Jiang, T., Luo, S., Chen, Q., Shen, L., \& Y ing, T. (2010). Effect of integrated application of gamma irradiation and modified atmosphere packaging on 
physicochemical and microbiological properties of shiitake mushroom (Lentinus edodes). F ood Chemistry, 122, 761-767.

Kala", P. (2009). Chemical composition and nutritional value of European species of wild growing mushrooms: A review. Food Chemistry, 113, 9-16.

Kavishree, S., Hemavathy, J., Lokesh, B.R., Shashirekha, M.N., \& Rajarathnam, S. (2008). Fat and fatty acids in Indian edible mushrooms. Food Chemistry, 106, 597-602.

Nawar, W.W. (1986). Volatiles from food irradiation. Food Reviews International, 2 , $45-78$.

O uzouni, P.K ., \& Riganakos, K .A. (2007). Nutritional value and metal content of Greek wild edible fungi. Acta Alimentaria, 36, 99-110.

Patras, A., Brunton, N.P., Downey, G., Rawson, A., Warriner, K., \& Gernigon, G. (2011). A pplication of principal component and hierarchical cluster analysis to classify fruits and vegetables commonly consumed in Ireland based on in vitro antioxidant activity. J ournal of F ood Composition and Analysis, 24, 250-256.

Poucheret, P., Fons, F., \& Rapior, S. (2006). Biological and pharmacological activity of higher fungi: 20-Y ear retrospective analysis. M ycologie, 27, 311-333.

Rama, V., \& Jacob, J.P. (2000). Effects of methods of drying and pretreatments on quality of dehydrated mushroom. Indian F ood Packer, 54, 59-64.

Sommer, I., Schwartz, H., Solar, S., \& Sontag, G. (2010). Effect of gamma-irradiation on flavour 50-nucleotides, tyrosine, and phenylalanine in mushrooms (Agaricus bisporus). F ood Chemistry, 123, 171-174.

W alde S.G., V elu, V., Jyothirmayi, T., \& M ath, R.G. (2006). Effects of pretreatments and drying methods on dehydration of mushroom. J ournal of Food Engineering, $74,108-115$. 
WHO (World Health Organisation). (1994). Safety and nutritional adequacy of irradiated food. WHO, Geneva. 
Table 1. M oisture content ( $\mathrm{g} / 100 \mathrm{~g} \mathrm{fw})$, proximate composition ( $\mathrm{g} / 100 \mathrm{~g} \mathrm{dw}$ ) and energetic value $(\mathrm{kcal} / 100 \mathrm{~g} \mathrm{dw})$ of fresh and processed Macrolepiota procera samples. The results are presented as mean $\pm \mathrm{SD}(n=36)^{1}$.

\begin{tabular}{llcccccc}
\hline & & M oisture $^{4}$ & Fat & Protein & Carbohydrates & A sh & Energetic value \\
\hline \multirow{4}{*}{ Samples } & Fresh & $85.9 \pm 0.3 \mathrm{~b}$ & $2.9 \pm 0.1 \mathrm{~b}$ & $19 \pm 1 \mathrm{c}$ & $70 \pm 1 \mathrm{a}$ & $8.0 \pm 0.2 \mathrm{c}$ & $383 \pm 1 \mathrm{~b}$ \\
& Frozen & $87.7 \pm 0.3 \mathrm{a}$ & $2.2 \pm 0.1 \mathrm{c}$ & $28.6 \pm 0.5 \mathrm{a}$ & $60 \pm 1 \mathrm{~d}$ & $9.0 \pm 0.2 \mathrm{~b}$ & $375 \pm 1 \mathrm{c}$ \\
& Dried & $87.4 \pm 0.3 \mathrm{a}$ & $2.7 \pm 0.2 \mathrm{~b}$ & $19.8 \pm 0.4 \mathrm{~b}$ & $67 \pm 1 \mathrm{c}$ & $10.3 \pm 0.3 \mathrm{a}$ & $372 \pm 1 \mathrm{~d}$ \\
& Irradiated & $85.8 \pm 0.3 \mathrm{~b}$ & $3.6 \pm 0.5 \mathrm{a}$ & $20 \pm 1 \mathrm{~b}$ & $69 \pm 1 \mathrm{~b}$ & $7.6 \pm 0.3 \mathrm{~d}$ & $388 \pm 3 \mathrm{a}$ \\
\hline Homocedasticity $^{2}$ & p-value & 0.792 & 0.015 & 0.331 & 0.556 & 0.298 & 0.021 \\
\hline One-way A N OV A $^{3}$ & p-value & $<0.001$ & $<0.001$ & $<0.001$ & $<0.001$ & $<0.001$ & $<0.001$
\end{tabular}

${ }^{1} M$ eans within a column with different letters differ significantly $(p<0.05)$, evaluated either using the multiple comparison Tukey's HSD or Tamhane's T2 tests, depending on the fulfilment or not of the homoscedasticity requirement.

${ }^{2} \mathrm{H}$ omoscedasticity among processing technologies was tested by means of the Levene test.

${ }^{3} p<0.05$ indicates that the mean value of the evaluated parameter of at least one sample differs from the others (in this case multiple comparison tests were performed).

${ }^{4} \mathrm{M}$ oisture content was evaluated by lyophilization for fresh, frozen and irradiated samples; in the case of dry samples, water was removed using an oven.

fw- F resh weight; dw - Dry weight. 
Table 2. Fatty acids composition (g/100 g of fat) of fresh and processed Macrolepiota procera samples. The results are presented as mean $\pm \mathrm{SD}(\mathrm{n}=36)^{1}$.

\begin{tabular}{|c|c|c|c|c|c|c|c|c|c|c|c|c|c|}
\hline & & $\mathrm{C} 14: 0$ & $\mathrm{C} 15: 0$ & C16:0 & C16:1 & $\mathrm{C} 18: 0$ & C18:1 & $\mathrm{C} 18: 2$ & $\mathrm{C} 20: 2$ & $\mathrm{C} 24: 0$ & SFA & MUFA & PUFA \\
\hline \multirow{4}{*}{ Samples } & Fresh & $0.34 \pm 0.01 \mathrm{a}$ & $0.30 \pm 0.01 \mathrm{~d}$ & $21.4 \pm 0.2 \mathrm{~b}$ & $1.29 \pm 0.03 \mathrm{~b}$ & $1.77 \pm 0.03 \mathrm{c}$ & $7.6 \pm 0.1 \mathrm{~b}$ & $65.0 \pm 0.2 \mathrm{~b}$ & $0.46 \pm 0.01 \mathrm{~b}$ & $0.78 \pm 0.02 \mathrm{~b}$ & $25.2 \pm 0.2 \mathrm{~b}$ & $9.3 \pm 0.1 \mathrm{~b}$ & $65.5 \pm 0.2 \mathrm{~b}$ \\
\hline & Frozen & $0.28 \pm 0.01 \mathrm{~b}$ & $0.37 \pm 0.01 \mathrm{~b}$ & $18.2 \pm 0.3 \mathrm{c}$ & $1.07 \pm 0.02 \mathrm{c}$ & $1.46 \pm 0.03 \mathrm{~d}$ & $5.7 \pm 0.3 \mathrm{~d}$ & $71.0 \pm 0.3 \mathrm{a}$ & $0.107 \pm 0.002 \mathrm{c}$ & $0.52 \pm 0.02 \mathrm{c}$ & $21.4 \pm 0.3 \mathrm{c}$ & $6.9 \pm 0.4 \mathrm{~d}$ & $71.6 \pm 0.4 \mathrm{a}$ \\
\hline & Dried & $0.35 \pm 0.01 \mathrm{a}$ & $0.41 \pm 0.01 \mathrm{a}$ & $22.7 \pm 0.5 \mathrm{a}$ & $1.23 \pm 0.03 \mathrm{~b}$ & $2.32 \pm 0.05 \mathrm{a}$ & $6.8 \pm 0.1 \mathrm{c}$ & $63 \pm 1 \mathrm{c}$ & $0.76 \pm 0.02 \mathrm{a}$ & $0.85 \pm 0.02 \mathrm{a}$ & $28 \pm 1 \mathrm{a}$ & $8.5 \pm 0.2 \mathrm{c}$ & $64 \pm 1 \mathrm{c}$ \\
\hline & Irradiated & $0.34 \pm 0.02 \mathrm{a}$ & $0.33 \pm 0.01 \mathrm{c}$ & $22 \pm 1 \mathrm{a}$ & $1.5 \pm 0.1 \mathrm{a}$ & $2.0 \pm 0.1 \mathrm{~b}$ & $8.3 \pm 0.5 \mathrm{a}$ & $62 \pm 2 \mathrm{c}$ & $0.56 \pm 0.03 \mathrm{~b}$ & $0.86 \pm 0.05 \mathrm{a}$ & $27 \pm 1 \mathrm{a}$ & $10 \pm 1 \mathrm{a}$ & $63 \pm 2 c$ \\
\hline Homocedasticity $^{2}$ & $p$-value & 0.186 & 0.086 & 0.001 & 0.001 & 0.042 & 0.006 & 0.001 & $<0.001$ & 0.031 & 0.001 & $<0.001$ & $<0.001$ \\
\hline One-way ANOVA ${ }^{3}$ & $p$-value & $<0.001$ & $<0.001$ & $<0.001$ & $<0.001$ & $<0.001$ & $<0.001$ & $<0.001$ & $<0.001$ & $<0.001$ & $<0.001$ & $<0.001$ & $<0.001$ \\
\hline
\end{tabular}

${ }^{1}$ Means within a column with different letters differ significantly $(p<0.05)$, evaluated either using the multiple comparison Tukey's HSD or Tamhane's T2 tests, depending on the fulfilment or not of the homoscedasticity requirement.

${ }^{2}$ Homoscedasticity among processing technologies was tested by means of the Levene test.

${ }^{3} p<0.05$ indicates that the mean value of the evaluated parameter of at least one sample differs from the others (in this case multiple comparison tests were performed). 
Table 3. Tocopherols composition $(\mu \mathrm{g} / 100 \mathrm{~g} \mathrm{dw})$ of fresh and processed Macrolepiota procera. The results are presented as mean $\pm \mathrm{SD}(\mathrm{n}=36)^{1}$.

$\alpha$-Tocopherol $\beta$-Tocopherol $\gamma$-Tocopherol $\delta$-Tocopherol Total tocopherols

\begin{tabular}{lllllll}
\hline & Fresh & $2.8 \pm 0.4 \mathrm{c}$ & $51 \pm 3 \mathrm{~b}$ & $32 \pm 3 \mathrm{c}$ & $91 \pm 3 \mathrm{a}$ & $178 \pm 9 \mathrm{a}$ \\
& Frozen & $2.5 \pm 0.2 \mathrm{c}$ & $54 \pm 4 \mathrm{~b}$ & $9 \pm 1 \mathrm{~d}$ & $81 \pm 4 \mathrm{~b}$ & $146 \pm 3 \mathrm{~b}$ \\
& Dried & $4.5 \pm 0.3 \mathrm{~b}$ & $77 \pm 8 \mathrm{a}$ & $38 \pm 1 \mathrm{~b}$ & $65 \pm 1 \mathrm{~d}$ & $185 \pm 8 \mathrm{a}$ \\
& Irradiated & $5.2 \pm 0.5 \mathrm{a}$ & $26 \pm 6 \mathrm{c}$ & $43 \pm 1 \mathrm{a}$ & $72 \pm 7 \mathrm{c}$ & $146 \pm 12 \mathrm{~b}$ \\
\hline Homocedasticity $^{2}$ & $p$-value & $<0.001$ & $<0.001$ & $<0.001$ & $<0.001$ & 0.001 \\
\hline One-way ANOVA $^{3}$ & $p$-value & $<0.001$ & $<0.001$ & $<0.001$ & $<0.001$ & $<0.001$
\end{tabular}

${ }^{1}$ Means within a column with different letters differ significantly $(p<0.05)$, evaluated either using the multiple comparison Tukey's HSD or Tamhane's T2 tests, depending on the fulfilment or not of the homoscedasticity requirement.

${ }^{2}$ Homoscedasticity among processing technologies was tested by means of the Levene test.

${ }^{3} p<0.05$ indicates that the mean value of the evaluated parameter of at least one sample differs from the others (in this case multiple comparison tests were performed). 
Table 4. Free sugars composition $(\mathrm{g} / 100 \mathrm{~g} \mathrm{dw})$ of fresh and processed Macrolepiota procera. The results are presented as mean $\pm \mathrm{SD}(\mathrm{n}=36)^{1}$.

\begin{tabular}{llccccc}
\hline & & Fructose & Mannitol & Trehalose & Melezitose & Total sugars \\
\hline & Fresh & $0.06 \pm 0.01 \mathrm{c}$ & $5.2 \pm 0.1 \mathrm{~b}$ & $9.1 \pm 0.3 \mathrm{~b}$ & $1.24 \pm 0.05 \mathrm{~b}$ & $15.7 \pm 0.4 \mathrm{c}$ \\
Samples & Frozen & $0.17 \pm 0.03 \mathrm{a}$ & $4.9 \pm 0.1 \mathrm{c}$ & $3.0 \pm 0.1 \mathrm{~d}$ & $0.25 \pm 0.01 \mathrm{~d}$ & $8.3 \pm 0.2 \mathrm{~d}$ \\
& Dried & $0.10 \pm 0.01 \mathrm{~b}$ & $11.4 \pm 0.2 \mathrm{a}$ & $6.8 \pm 0.2 \mathrm{c}$ & $1.02 \pm 0.04 \mathrm{c}$ & $19.3 \pm 0.4 \mathrm{a}$ \\
& Irradiated & $0.054 \pm 0.002 \mathrm{c}$ & $5.1 \pm 0.3 \mathrm{bc}$ & $10.2 \pm 0.2 \mathrm{a}$ & $1.42 \pm 0.05 \mathrm{a}$ & $16.7 \pm 0.5 \mathrm{~b}$ \\
\hline Homocedasticity $^{2}$ & $p$-value & $<0.001$ & 0.043 & 0.008 & 0.014 & 0.011 \\
\hline One-way ANOVA $^{3}$ & $p$-value & $<0.001$ & $<0.001$ & $<0.001$ & $<0.001$ & $<0.001$
\end{tabular}

${ }^{1}$ Means within a column with different letters differ significantly $(p<0.05)$, evaluated either using the multiple comparison Tukey's HSD or Tamhane's T2 tests, depending on the fulfilment or not of the homoscedasticity requirement.

${ }^{2}$ Homoscedasticity among processing technologies was tested by means of the Levene test.

${ }^{3} p<0.05$ indicates that the mean value of the evaluated parameter of at least one sample differs from the others (in this case multiple comparison tests were performed). 
Table 5. Antioxidant activity $\left(\mathrm{EC}_{50} ; \mathrm{mg} / \mathrm{mL}\right)$ and total phenolics content (mg GAE/g extract) of fresh and processed Macrolepiota procera. The results are presented as mean $\pm \mathrm{SD}(\mathrm{n}=36)^{1}$.

\begin{tabular}{|c|c|c|c|c|c|c|}
\hline & & DPPH scavenging activity & Reducing power & $\beta$-carotene bleaching inhibition & TBARS formation inhibition & Phenolics \\
\hline \multirow{4}{*}{ Samples } & Fresh & $4.9 \pm 0.4 \mathrm{~b}$ & $1.44 \pm 0.02 \mathrm{~b}$ & $6.7 \pm 0.5 \mathrm{~b}$ & $1.97 \pm 0.03 \mathrm{c}$ & $18.2 \pm 0.1 \mathrm{~b}$ \\
\hline & Frozen & $3.7 \pm 0.2 \mathrm{c}$ & $1.27 \pm 0.01 \mathrm{~d}$ & $8.3 \pm 0.2 \mathrm{a}$ & $3.5 \pm 0.2 \mathrm{~b}$ & $15.3 \pm 0.1 \mathrm{~d}$ \\
\hline & Dried & $2.7 \pm 0.1 \mathrm{~d}$ & $1.35 \pm 0.01 \mathrm{c}$ & $1.10 \pm 0.05 \mathrm{~d}$ & $4.08 \pm 0.05 \mathrm{a}$ & $19.2 \pm 0.2 \mathrm{a}$ \\
\hline & Irradiated & $7.9 \pm 0.5 \mathrm{a}$ & $1.74 \pm 0.01 \mathrm{a}$ & $2.5 \pm 0.4 \mathrm{c}$ & $0.78 \pm 0.05 \mathrm{~d}$ & $17.1 \pm 0.4 \mathrm{c}$ \\
\hline Homocedasticity $^{2}$ & $p$-value & $<0.001$ & $<0.001$ & 0.017 & $<0.001$ & $<0.001$ \\
\hline One-way ANOVA ${ }^{3}$ & $p$-value & $<0.001$ & $<0.001$ & $<0.001$ & $<0.001$ & $<0.001$ \\
\hline
\end{tabular}

${ }^{1}$ Means within a column with different letters differ significantly $(p<0.05)$, evaluated either using the multiple comparison Tukey's HSD or Tamhane's T2 tests, depending on the fulfilment or not of the homoscedasticity requirement.

${ }^{2}$ Homoscedasticity among processing technologies was tested by means of the Levene test.

${ }^{3} p<0.05$ indicates that the mean value of the evaluated parameter of at least one sample differs from the others (in this case multiple comparison tests were performed). 

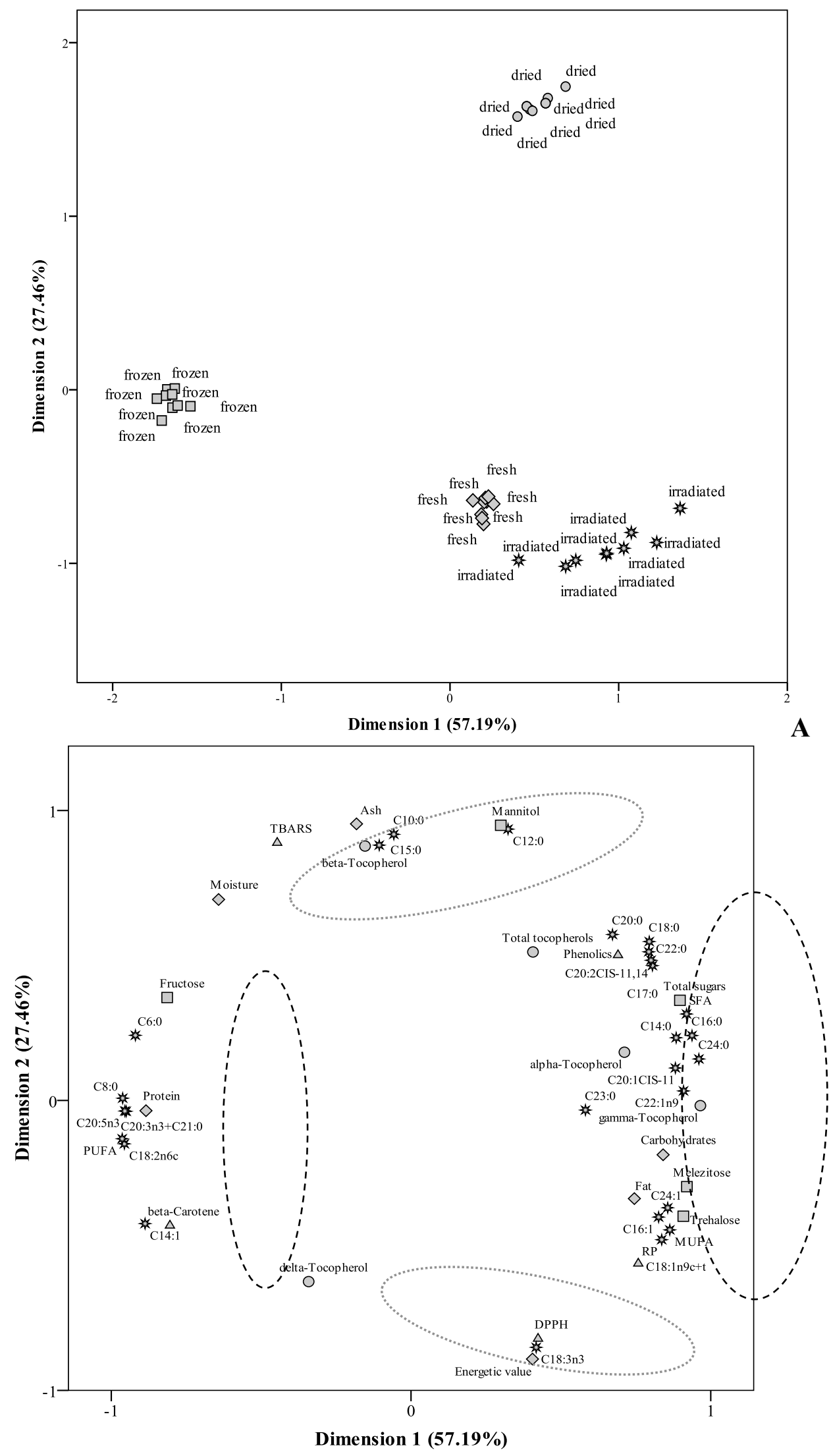

Figure 1. Object points labeled by processing technology (A) and component loadings (B) plot. Each group of assayed parameters (proximate composition, fatty acids, tocopherols, free sugars and antioxidant activity) is identified with a different symbol. 